\title{
THE REFORM
}

OF

\section{SOVIET PROCURATORIAL LEGISLATION}

\author{
Hiroshi ODA \\ (Univ. of Tokyo)
}

In November 1979, the Supreme Soviet of the USSR promulgated a new law on the procuracy. 1) It was a part of the legislative reform which followed the new Soviet Constitution of 1977. Other important legislation, for example the statute on the USSR Supreme Court, the statute on advocates and the statute on arbitration, was promulgated at the same time.

The prototype of the contemporary procuratorial system of the USSR was formulated by the RSFSR statute on the procuracy of May 22, 1922. In 1933, this system was reorganized and the All Union Procuracy was established. After the death of Stalin, the statute on the Procuracy was one of the first pieces of legislation to be amended in order to "restore" socialist legality. Thus, in 1955 a new statute on the Procuracy was enacted. ${ }^{2)}$ This statute merely unified the then existing, sporadic legislation, ministrial instructions and circulars. The fundamental structure and competence of the Procuracy remained unchanged in this statute. The new law on the Procuracy of 1979 totally amended the 1955 statute. The range and the scope of the changes which it brought about exceed those of the previous two reforms of 1933 and 1955.3)

1. Vedomosti Verkhovnogo Soveta SSSR, 1979, No. 49 Art. 843.

2. Vedomosti Verkhounogo Soveta SSSR, 1955, No. 9 Art. 222.

3. Regarding the history of Soviet Procuracy, $c f$. G. Morgan, Soviet Administrative Legality, Stanford, 1962, pp. 22-130. 
Because the statute of 1955 did not introduce any changes in the procuratorial system and was not immune from various shortcomings, by the late 1950s, further amendment of the legislation was being proposed.4) Especially after the large scale legislative reform which began from 1958, the adjustment of the statute to the new legislation became necessary. In 1965, there was an abortive attempt to enact a new law on the Procuracy. 5) Following an article written by S. G. Berezovskaia, V. K. Zvirbul', S. G. Novikov and M. Iu. Raginskii asserting the necessity to amend the statute, discussion regarding the reform took place among the procurators and scholars. ${ }^{6}$ ) According to G. A. Murashin, the reform was intended to promote the democratic principle of the Soviet Procuracy, to activate mass participation in the activities of the Procuracy and to increase the effectiveness of the procuratorial supervision. ${ }^{7)}$

Even after this attempt of reform failed, proponents of the reform were influential. L. A. Nikolaeva cites a census of 1972 and 1975, in which more than half of the respondents who were mainly procurators criticized that the 1955 statute did not precisely define the competence and the task of the Procuracy.8) They also pointed out that the scope of the procuratorial supervision was unclear. According to another source, 92 percent of the cadres of the Procuracy admitted the necessity of reform and made various proposals. Meanwhile, in the East European countries such as Poland, the DDR and Hungary, a new law on the Procuracy was enacted.

The Constitution of 1977 declared the principle of socialist legality to be a fundamental principle of the Soviet Union. Accordingly, the authority of the Procuracy as a guardian of legality was increased, which can be proved by the fact that the Constitution newly included a specific chapter regarding the Procuracy.9) After the promulgation of the Constitution, a decree of the

4. Sovetskoe Gosudarstvo i Pravo, 1965, No. 8, p. 36.

5. M. Maliarov, who was the first deputy of the Procurator General, stated that the legislation on the Procuracy requires reform in 1965. cf. Sotsialisticheskaia Zakonnost', 1965, No. 8, p. 36.

6. Sovetskoe Gosudarstvo i Pravo, 1965, No. 3, pp. 42-49; 1966, No. 1, pp. 131-136.

7. G. A. Murashin, Oragny prokuratury v mekhanizme sovetskogo gosudarstva, Kiev, 1972, pp. 126-127.

8. L. A. Nikolaeva, Prokuratura i zakonnost'v sovetskom gosudarstvennom upravlenii, Leningrad, 1978, p. 36; Murashin, op. cit. p. 126.

9. Cf. Art. 164-168 of the USSR Constitution. 
USSR Supreme Soviet listed a series of legislations to be amended in order to bring them in accordance to the Constitution, including the statute on the Procuracy.

The All Union Procuracy, the Supreme Court and the Ministry of Justice took the initiative in the drafting of the new law. The Ministry of Internal Affairs and the Committee of State Security participated in this process. ${ }^{10}$ ) In the legislateve process, procurators and legal scholars made proposals on various points. These proposals were published in the legal periodicals and monographs. Unlike the drafting of the Constitution, the proposals of these specialists seem to have had some effect on the legislation. The draft was submitted to the legislative committee of the USSR Supreme Soviet after the discussion at the collegium of the All Union Procuracy. The Supreme Soviet of the USSR promulgated the law on 29 th of November.

The new legislation was titled the "Law on the Procuracy" whereas the 1955 legislation was titled the "Statute on the Procuracy". During the period when the 1955 statute was in force, some lawyers objected that the statute (polozhenie) form of legislation was not suitable for an agency which is charged with the "supreme supervision" of socialist legality, although it may be suitable for ordinary administrative agencies. ${ }^{11)}$ Article 164 of the new Constitution accepted this argument and stated that the Procuracy should be regulated by law (zakon).

The law on the Procuracy is composed of four parts, 49 articles in all. Following the first part which is the general part of law, the second part deals with the organization and system of the Procuracy. Part three is devided into four chapters in which each major function of the Procuracy is regulated in detail. Also, the form of activity and the competence of the Procuracy are defined in this part. Part four deals with miscellaneous issues.

The new law listed the following functions as the major task of the Procuracy: 1) supervision of strict observance of law by administrative agencies, state enterprises, social organizations, government officials and citizens (general supervision) 12) 2) supervision of the observance of legality by agencies of inquiry and of preliminary investigation 3) struggle against crimes and other

10. Sotsialisticheskaia Zakonnost', 1976, No. 6, pp. 47-48.

11. Sovetskoe Gosudarstvo i Pravo, 1966, No. 1, p. 133.

12. This is the first time the term "general supervision" was used in the legislation. 
violations of law, investigation of crimes and the prosecution of the offender 4) supervision of the observance of law at trial 5) supervision of the strict observance of law at the corrective labour institutions and places of preliminary detention and also the supervision of the enforcement of penalties and other measures of compulsive nature. In addition to these five functions which were already provided in the previous statutes, the new law provided several new functions of the Procuracy: 1) taking measures to prevent crimes and other violations of law in cooperation with other agencies such as the agencies of the Ministry of Internal Affairs, the Ministry of Justice and the Supreme Court 2) coordination of the activities of the agencies in charge of the struggle against crimes and other violations of law (Art. 3).

Since the late 1960s, the Soviet leadership began to emphasize the significance of establishing state and social discipline in order to secure the efficiency and effectiveness of the governmental and economic systems. Consequently, not only the correction of violations of the law but also their prevention became more and more important. ${ }^{13}$ ) The Procuracy was expected to play a major role in this preventive activity. Due to the economic difficulties in the USSR in the early 1970s, prevention of crimes and other violations of the law in the area of economic activity was stressed. Thus, the struggle against substandard production, petty larceny of state property and unconscientious attitude towards state property etc. became a major part of the activity of the Procuracy. ${ }^{14)}$ As regards to this point, it should be noted that the struggle against the violation of the law protecting socialist property was separately defined as one of the functions of the Procuracy, which reminds Western sovietologists of the law of 1932 (Art. 3).

\section{II}

The main function of the Soviet Procuracy is general supervision, i.e., the supervision of the strict observance of law by administrative agencies, govern-

13. Kommunist, 1979, No. 14, pp. 3-6; Sotsialisticheskaia Zakonnost', 1976, No. 5, pp. 3-5.

14. Sotsialisticheskaia Zakonnost', 1979, No. 11, pp. 6-9. The author of this article is the director of the branch of general supervision of the USSR Procuracy. 
ment officials and others. ${ }^{15)}$ The system of general supervision has its genesis in Tsarist Russia. Today, it is an institution peculiar to the socialist countries. Poland, the DDR, Hungary, Bulgaria and some other countries have also adopted this system after the Second World War.

The objects of this general supervision are: Ministries, State Committees, departments, enterprises, executive and administrative agencies of local Soviets, cooperatives and other social organizations, government officials and citizens (Art. 22). Whether the competence of the Procuracy covers agencies other than those listed in the statute has been disputed. It was generally recognized in the USSR that the USSR Supreme Soviet and the Council of Ministers are immune from the supervision of the Procuracy. The focus of the debate was the question of whether the Supreme Soviet and the Council of Ministers of the Union republic should be subject to supervision or not. The opinion which holds that the Council of Ministers of the Union republic should also be subjected to supervision was influential in the mid 1960s and was supported by S. G. Novikov and others at this time. ${ }^{16)}$ In practice, there was a case where a presentation was lodged against the act of the Supreme Soviet of the Union republic by the Procurator of the republic. ${ }^{17)}$ The clarification of this problem by legislation was proposed by procurators and lawyers. Neverthless, the new law refrained from listing these two agencies as the object of supervision. Presumably, the reason has something to do with the granting of power of binding force to the presentation of the Procuracy. If a presentation were to have binding force on the addressant, it might be difficult to provide that an agency which is supposed to be the supreme body of the Union republic is subject to supervision of the Procuracy.

The Procuracy supervises not only the individual decisions of the agencies listed in the law, but also subordinate legislations enacted by these agencies as well. In the USSR, the court does not have jurisdiction over the legality of subordinate legislations. Therefore, the general supervision of the Procuracy

15. Regarding the general supervision, see G. Smith, Soviet Procuracy and the Supervision of Administration, Alphen aan den Rijn, 1978.

16. Sovetskoe Gosudarstvo i Pravo, 1965, No. 3, p. 38; Sotsialisticheskaia Zakonnost', 1973, No. 3, p. 38.

17. S. G. Berezovskaia, Okhrana prav grazhdan sovetskoi prokuraturoi, Moscow, 1964 , pp. 49-50. 
is the main device of Normenkontrolle.

The Procuracy has a broad competence to carry out general supervision. As a measure to expose violations of the law, the procurator may request administrative agencies and government officials to send him copies of their decisions and instructions. Furthermore, he may ask the director and officials of these agencies to send him the relevant materials and documents. $\mathrm{He}$ is also empowered to inspect the activity of these agencies and summon government officials and citizens to hear their explanations regarding violations of law (Art. 23). The request of the procurator is binding on the government officials and citizens. According to the 1955 statute, the request of the procurator was binding only on government officials. Some procurators asserted that in the event that government officials or citizens refuse a request of the procurator without reasonable grounds, the procurator should be empowered to take certain measures. ${ }^{18)}$ The new law partly accepted this proposal and extended the scope of the binding force of the request to ordinary citizens in order to improve the effectiveness of the procuratorial action (Art. 24). However, as yet, the problem of what kind of measures may be expected in the event of refusal of a request is unsolved.

If the procurator exposes the violation of law, in order to correct it and to remove the cause of the violation, there are several alternatives he may take. The 1955 statute merely provided for protest and presentation. Most of the procurators have been criticizing the insufficiency of the regulation concerning this point. The new law systematized the articles regarding the action which is to be taken by the procurator and added other measures, such as the decision to transfer the offender to criminal and civil proceedings, and also warnings.

The major alternative open to the procurator in order to correct violations of law and remove their cause is the protest and presentation. According to the new law, protest takes the form of the procurator's requesting the administrative agencies, social organizations and other bodies to repeal or amend the illegal decisions, to suspend their enforcement of the action taken by government officials and to make compensation for the damage caused

18. Sotsialisticheskaia Zakonnost', 1978, No. 8, p. 34 ; No. 1976 No. 6, p. 47.

19. Sotsialisticheskaia Zakonnost', 1979, No. 2, p. 45 ; No. 5 , p. 47. 
by their actions (Art. 25). Presentation is a device requesting certain agencies and government officials to take measures to correct the violation of law and to remedy the situation which made it possible for the violation to occur (Art. 26).

In the 1955 statute, the distinction between the two was not made clear. Neither of them had binding force, however, the addressant of the protest was obliged to consider whether to accept the protest or to appeal within 10 days. Moreover, in certain categories of cases, the lodging of the protest suspended the enforcement of the decision of administrative agencies. In this sense, it can be said that protest had a stronger effect than presentation. Generally, protests were used as a corrective measure, whereas presentations were used as a measure to prevent further violations of laws and to remedy the situation which caused the violation. Moreover, protests were used in cases of individual violations of law. ${ }^{20)}$ Since the early 1970s, procurators tend to utilize presentation rather than protest. ${ }^{21)}$ This shift seems to correspond to the fact that prevention of crimes and other violations of law gained priority since the early 1970 s.

Furthermore, the new law strengthened the legal effect of presentation. It was a general rule that protests and presentations of the procurator were not binding on the addressant. When the establishment of the Procuracy was considered in 1922, N. V. Krylenko, who drafted the statute on the Procuracy, defended the draft against the opposition to the establishment of the Procuracy on the ground that the measures taken by the Procuracy were not compulsive. Although these measures did not have binding force, practically speaking, 95\% of the protests lodged were accepted by the addressant. ${ }^{22)}$ Therefore, the problem of granting binding force to protest did not seem to have actual significance. Rather, the discussion was focused around the problem of the suspending effect of the protest. However, in the course of debate regarding the new law on the Procuracy, some procurators pointed out the necessity of granting the power of binding force to the measures taken by the

20. Nikolaeva, op. cit.; in 1972 , the Procuracy lodged approximately 62,000 protests and 60,000 presentations.

21. Smith, op.cit., pp. 88-90.

22. Sovetskoe Gosudarstvo i Pravo, 1965, No. 3, p. 44.

23. Sotsialisticheskaia Zakonnost', 1978, No. 8, p. 33; No. 12, p. 57. 
procurator. ${ }^{23)}$ Some procurators asserted that the procurator should demand and instruct rather than make request of the addressant. ${ }^{24)}$ The new law partly accepted this proposal and stated that the request of the procurator to correct a violation of law and to remove its cause and the situation which made the violation of law possible are binding on the addressant (Art. 24). Whether this provision means that not only presentation but also protest was granted binding force is not clear. Articles which were published after the promulgation of the new law seem to imply that this provision is applicable only to presentations. ${ }^{25)}$

Although the new law strengthened the power of the Procuracy, on the other hand, it did not provide any means of contesting the grounds and legality of measures taken by the Procuracy. The procedure by which an addressant may contest these measures is not established. Judging from former practice, the addressant should appeal to the superior procurator in such cases.

Furthermore, the scope of the suspending effect of the protest was expanded by the new law. In the 1955 statute, the suspension of the enforcement of the decisions of the administrative agencies by lodging of a protest was recognized only in cases where protests were lodged against illegal imposition of administrative sanctions. The opinion asserting that the scope of this provision should be expanded was quite influential during the period in which the 1955 statute was in force. It was pointed out that the enforcement of the decision of the administrative agencies which has been the subject of protest is likely to cause damage impossible to remedy and thus infringe the rights of the citizens. ${ }^{26)}$ During the discussion regarding the reform, this opinion gained support among the procurators. ${ }^{27)}$ The new law accepted this argument and provided that protests against acts which violate the rights and lawful interests of the citizens and other acts provided by the law suspend their enforcement while the question of whether or not to comply with the protest is considered by the addressant (Art. 25 - IV).

Along with protests and presentations, the new law formalized the right of

24. Sotsialisticheskaia Zakonnost', 1979, No. 6, p. 48.

25. Vestnik Moskovskoge Universiteta, (law), 1980, No. 3, pp. 7-8; Sotsialisticheskaia Zakonnost', 1980, No. 12, p. 25.

26. Sovetskoe Gosudarstvo i Pravo, 1965, No. 3, pp. 43-44.

27. S. G. Novikov, Prokurorskaia sistema v SSSR, Moscow, 1977, pp. 164-165. 
the procurator to decide whether to transfer the person responsible for the violations of law to criminal, civil, administrative and disciplinary proceedings (Art. 27). In practice, the procurator made a decision to transfer the offender to these proceedings, but the form and the effect of this kind of decision were not clarified in the statute. The vagueness regarding this point was criticized by some procurators. ${ }^{28)}$ The 1979 law newly provided a "decision" as one of the forms of procuratorial action. According to the new law, the procurator should express the reason of this decision. Also, the law provided that the decision to initiate administrative and disciplinary proceedings should be considered by the administrative agencies within 10 days.

General supervision also functions as a means of administrative remedy in the USSR. In the Western countries, the primary means of administrative remedy is to bring a case to court. In the Soviet Union, the jurisdiction of the court regarding administrative affairs is narrowly limited. Consequently, general supervision plays a significant role in this respect. ${ }^{29)}$ A Soviet citizen may submit a petition to the procurator's office when his rights are violated. After considering the case, if the procurator reaches the conclusion that the petition was justified, he takes the above mentioned measures such as protests, presentations etc. to correct the violation of law and remedy the interest of the citizen.

The ineffectiveness of this system of petition as a means of administrative remedy has been recognized and criticized even by Soviet lawyers since the mid 1950s. After the submission of the petition to the procurator, the petitioner has no opportunity to defend his case in public and argue with the opposing party. The case is dealt with in camera without the participation of the parties. Thus the disposition of the case is left solely to the discretion of the procurator. ${ }^{30)}$

In order to expand the publicness of the disposition of the petition, in some of the procurator's offices, the practice is to inform the petitioner how the case is proceeding and what the administrative agency's counterarguments

28. Sotsialisticheskaia Zakonnost', 1978, No. 8, p. 34.

29. Cf. L. Boim, "Ombudsmanship in the Soviet Union", The American Journal of Comparative Law, 1974, No. 3, pp. 511-516; W. Gellhorn, Ombudsman and others, Cambridge, 1966, pp. 367-370.

30. L. Boim, op. cit. 


\section{HIROSHI ODA}

are. ${ }^{31)}$ However, this practice is not generally accepted. The new law made only one provision regarding the disposition of the petition by the procurator (Art. 45). The legal status of the citizen concerning the petition remains insufficient as before.

Related to this point is the expansion of the jurisdiction of the court over administrative affairs. It should be noted that the proposal to expand the jurisdiction of the court is influenced by the awareness of the Soviet lawyers of the insufficiency of the petition system as a means of administrative remedy. ${ }^{32)}$ The new Constitution provided the right of citizens to bring a case to court if their rights are violated by governmental officials. ${ }^{33)}$ Drafting of the new law on administrative remedy is now under way. In the course of discussion concerning the reform of the law on the Procuracy, the role of the procurator in administrative cases was also discussed. The inclusion of a provision regarding this problem, for example, empowering the procurator to bring the case to the court in place of the aggrieved citizens, was proposed. ${ }^{34}$ ) Although the new law does not define the role of the procurator in administrative cases, a supplement to the law is likely to become necessary when the law of administrative remedy is promulgated.

\section{III}

The Soviet procurator supervises the observance of legality at the pretrial stage of criminal procedure (Art. 28). In the Soviet criminal procedure, the pretrial stage is devided in to inquiry and preliminary investigation. The latter is different from its counterpart in the Civil law system in that the proceedings are presided over not by the juge de instruction but by the investigator attached to the Procuracy, the Ministry of Internal Affairs and the Commit-

31. Sotsialisticheskaia Zakonnost', 1979, No. 12, p. 12.

32. D. D. Barry, "Administrative Justice and Judicial Review in Soviet Administrative Law", Barry et al ads., Soviet law after Stalin, vol. 2, Alphen aan den Rijn, 1978, p.251.

33. Art. 58 of the USSR Constitution.

34. Sotsialisticheskaia Zakonnost', 1979, No. 1, p. 46; K. D. Burmistrov, Rol' prokurorskogo nadzora vobespechenii sotsialisticheskoi zakonnosti, Moscow, 1979, pp. $44-45$. 
tee of State Security. The statute of 1955 has been criticized for its insufficiency of the provisions regarding this function of the Procuracy. ${ }^{35)}$ Especially after the promulgation of the criminal procedural code of the Union republics, the necessity of amending the statute in accordance with the new codes became obvious. The new law on the Procuracy took in the provisions of the criminal procedural codes and defined the competence of the procurator in this respect in a more detailed way than the old statute. ${ }^{36)}$

The procurator may instruct the agencies of inquiry and preliminary investigation on matters regarding the investigation of crimes, the choice, alternation and revocation of the measures of restraint, application of the provisions of the criminal code. Furthermore, the procurator is empowered to revoke and alter the illegal decisions of the investigators and officials of inquiry (Art. 29 - I). The instructions of the procurator concerning the initiation of criminal procedure, inquiry and preliminary investigation of the case is binding on these officials (Art. 29 - II).

On the role of the procurator at the pretrial stage, there seems to have been a conflict of opinion between the Ministry of Internal Affairs and the Procuracy. Some officials of the Ministry of Internal Affairs proposed limiting the competence of the procurator to an ex post facto supervision. ${ }^{37)}$ On the other hand, some procurators proposed that the new law should explicitly set out the competence of the procurator to "direct" the investigation. ${ }^{38)}$ The new law does not include a general provision which empowers the procurator to direct the inquiry and preliminary investigation. However, it extended the competence of the procurator to instruct the investigators and of ficials of inquiry (Art. 29 - I).

The statute of 1955 contained a specific provision regarding the supervision of the legality of the detention of the accused. As Soviet officials admit, illegal detention of citizens by the police and other agencies is not rare in the Soviet Union. From time to time, cases of illegal detention are criticized in the legal periodicals. ${ }^{39)}$ According to the statute, the procurator is charged

35. Sotsialisticheskaia Zakonnost', 1979, No. 1, p. 47.

36. $C f$. Art. 211 of the RSFSR criminal procedural code.

37. Sovetskoe Gosudarstvo i Pravo, 1975, No. 3, pp. 74-75.

38. Sotsialisticheskaia Zakonnost', 1978, No. 11, p. 59; No. 10, pp. 56-57.

39. Sotsialisticheskaia Zakonnost', 1979, No. 9, p. 3; 1980, No. 3, p. 4. 
with ensuring that no one should be detained without the approval of the court or the procurator (Art. 30). During the recent discussion, some of the participants proposed to make the hearing of the accused obligatory, when the procurator decides whether to approve the detention or not. ${ }^{40)}$ However, the new law made the hearing obligatory only in cases where the accused are minors.

The reform of 1979 also clarified the role of the procurator at trial. The procurator participates in the trial in every instance of criminal and civil procedure, including the instance of judicial supervision and the reopening of the case by reason of newly discovered circumstances. The 1955 statute provided that the procurator shall supervise the legality of the judgement, decision and order of the court. However, it was not clear whether the procurator merely supervises the outcome of the trial or also supervises the process of the trial. There was a debate among the lawyers regarding this point. ${ }^{41}$ )

According to the criminal procedural code of the Union republic which was promulgated after the 1955 statute, the procurator has the right to contest the decision and order of the court and to object the actions of the defendant and defense counsel. However, the problem of whether the competence of the procurator was derived from his status as the state accusator or from his status as the agency of "judicial supervision" was problematic. The majority of the lawyers who participated in the discussion admitted that the procurator supervises the activity of the court and other parties at the trial, while the opinion led by M.S. Strogovich, which denied the supervision of the procurator at the trial and emphasized the procurator's role as a party, was still influential. ${ }^{42}$ ) Regarding this point, the new law explicitly provided that the procurator supervises the enforcement of law during the consideration of the case at the trial (Art. 31-I). He is expected to supervise the objective and thorough consideration of the case in every instance. On the other hand, a clause which obliges the procurator to observe the principle of

40. Sotsialisticheskaia Zakonnost', 1979, No. 1, p. 78;1978, No. 9, p. 37.

41. Sovetskoe Gosudarstvo i Pravo, 1966, No. 1, p. 136; M. Maliarov, ed., Prokurorskii nadzor v SSSR, third edition, Moscow, 1973, pp. 206-207; A. Bilinsky, "Kontroverse Meinungen zur Stellung des Staatsanwalts im sowjetischen Strafprozeß," Recht in Ost und West, 1971, Heft 5, S. 203-209.

42. M. S. Strogovich, Kurs sovetskogo ugolovnogo protsessa, Moscow, 1958, pp. 58-60. 
the independence of the judge was inserted in the new law (Art. 31 - II). The problem of how this principle and the system of "judicial supervision" by the procurator coincide remains unsolved. ${ }^{43)}$

Soviet procurators also function as a supervisor of the observance of law at the corrective labour institutions and other places of confinement (Art. 42). The new law extended the scope of supervision compared with the 1955 statute. The procurator supervises the observance of law in the execution of criminal sanctions without deprivation of freedom, and also the execution of those measures imposed by the court which are of a compulsive nature. The statute of 1955 only provided for the supervision of the places of deprivation of freedom. The expansion of the procuratorial supervision to other measures of a compulsive nature has been proposed. ${ }^{44)}$ The Federal Principle of Corrective Labour Law which was promulgated in 1968 listed banishment, exile and other sanctions imposed by the court as objects of procuratorial supervision. ${ }^{45)}$ In 1969, the Statute on Preliminary Detention empowered the procurator to supervise the detention. ${ }^{46)}$ Meanwhile, criminal sanctions without deprivation of freedom began to be widely utilized and the supervision of their execution became necessary. Following these developments, the new law on the Procuracy listed the penalty without deprivation of freedom and other measures of compulsive nature imposed by the court and also detention as objects of supervision. Measures of a compulsive nature imposed by the court include compulsory measures of a medical and educational character applied to the mentally deranged persons, alchoholics and drug adicts. ${ }^{47)}$

In order to supervise the observance of legality in this sphere, the procurator may visit the places of confinement and other institutions, have access to documents, accept petitions from persons confined and if necessary hear their objections. He may review the legality of the instruction, decision, order and other internal rules of the administration of these institutions. In the event that these acts are illegal, he may suspend their execution and lodge

43. Vgl. L. Révész, Justiz im Ostblock, Köln, 1967, S. 174-182.

44. Sovetskoe Gosudarstvo i Pravo, 1973, No. 3, p. 39.

45. Art. 10 of the Federal Principle of Corrective Labour Law.

46. Art. 19 , of the statu te on preliminary confinement.

47. Arts. 58-63 of the RSFSR criminal code. 
protests against them. When a procurator finds that a person is illegaly confined in these places, the procurator may order his release instantly. The decision and presentation of the procurator are binding on the administration of these institutions (Art. 43).

Due to the growing necessity of coordinating the activities of the agencies in charge of protection of law, many procurators proposed that the procurator should be assigned a primary role in the struggle against crime as a coordinator. ${ }^{48)}$ They proposed that the new law should include provisions regarding this function of the Procuracy and define the form of coordination. In practice, coordinating meetings are now organized at each level of the Procuracy. Representatives of the court, agencies of the Ministry of Internal Affairs and other agencies participate in this meeting. At the local level, the party organization is expected to take the initiative of the coordinating activity. ${ }^{49)}$ The new law provided the coordinating function in this sphere as a function of the Procuracy, but it failed to provide the form and method of coordination (Art. 3, Art. 14 - VI).

\section{IV}

There are several significant proposals which the legislator did not accept in the new law on the Procuracy. These abortive proposals seem to reflect the characteristics of the 1979 reform, so it is worth examining them in some detail.

The first problem is the democratic control of the activity of the Procuracy. The Procuracy is one of the most powerful agencies in the Soviet Union. External control of the legality of its activities is insufficient. The only effective control is through the party. When the establishment of the Procuracy was first discussed in 1922, there was a strong opposition to the establishment of such a centralized and independent agency. The opponents were apprehensive of the "bureaucratic distortion" of this agency. Owing to the support of the political leadership at that time, the Procuracy was eventually

48. Sotsialisticheskaia Zakonnost', 1978, No. 9, p. 37; 1979, No. 5, p. 48.

49. For example, cf. Sotsialisticheskaia Zakonnost', 1980, No. 8, p. 31; 1978, No. 9, p. 66 . 
established. However, the apprehension of the opponents proved to be correct under the rule of Stalin. After his death, the control of the Procuracy, especially the strengthening of the control of the USSR Supreme Soviet, was proposed. ${ }^{50)}$ During the discussion regarding the reform of 1979, it was proposed that the new law should make clear that the Procuracy supervises the observance of legality on behalf of the Supreme Soviet. ${ }^{51)}$ It was also proposed to make the submission of a periodic report to the Supreme Soviet, not to its Presidium, obligatory. 52) However, these proposals were not accepted. Admittedly, taking into account the nominal position of the Supreme Soviet which is supposed to be a supreme organ of the state, its control of the Procuracy is not likely to be effective. But the fact that some kind of control by the Supreme Soviet was proposed seems to be significant.

Related to this point is the proposal to empower the Supreme Soviet of the Union republic to appoint the republican procurator. ${ }^{53)}$ The proponents of this reform emphasized that in the 1920s, republican procurators who were at the same time people's commissars of Justice were appointed by the Central Executive Committee of the Union republic. It was only after the reform of 1933 that the appointment became the competence of the Procurator General. This proposal was also not accepted in the new law.

The second problem is the democratization of the Procuracy. Some lawyers, including S. G. Berezovskaia, asserted in vain that the introduction of openness (glastnost') in the activities of the Procuracy is necessary in order to secure its legality. ${ }^{54)}$ The term openness means not only the accessibility of citizens to the activities of the Procuracy in general, for example, an increase in the publication of protests and presentations. It also includes the interested party's access to the activities of the procuracy, especially the disposition of the administrative cases by means of general supervision, and to the relevant documents.

50. P. Vanneman, The Supreme Soviet: Politics and the Legislative Process in the Soviet Political System, Durham, 1977, pp. 113-115.

51. Sotsialisticheskaia Zakonnost', 1978, No. 10, p. 58; Nikolaeva, op. cit., p. 35.

52. Sotsialisticheskaia Zakonnost', 1978, No. 10, p. 58.

53. Murashin, op. cit., pp. 118-119.

54. Sotsialisticheskaia Zakonnost', 1978, No. 8, p. 32.

55. Sotsialisticheskaia Zakonnost', 1979, No. 12, pp. 11-12; Sovetskoe Gosudarstvo $i$ Pravo, 1979, No. 7, p. 111. 
Moreover, mass participation in the activity of the Procuracy was proposed. Some proponents asserted that representatives of trade union, comsomol, worker's collective and other social organization should participate in the collegium of the Procuracy. ${ }^{56)}$ In certain districts, the institution of lay assistant procurator has been adopted. ${ }^{57)}$ However, the extent of the participation of laymen in the activities of the Procuracy seems to be quite limited when compared with that of the lay assesor of the court. Notwithstanding the proposals, the new law did not provide for any kind of mass participation. ${ }^{58)}$

The proposal to introduce kollegialnost' in the decision making process of the Procuracy may also be regarded as an attempt to democratize the Procuracy to a certain extent. ${ }^{59)}$ Collegium of the Procuracy has been oraganized at each levels of the Procuracy by the instruction of the Procurator general in 1959. The new law provides for the organization, form of activities and competence of the collegium in detail. In the mid 1960s, there was a proposal to make the collegium not an advisory body, but one empowered to make decisions independently. ${ }^{60}$ ) On this point, the new law did not accept the proposal, but provided a means to coordinate the activities of the collegium and the procurator (Art. 19).

The third major problem is the clarification of the legal status of the party in relation to the Procuracy. The Communist Party of the USSR controls the activities of the Procuracy through various channels. For example, the appointment of the procurator requires approval at the appropriate level of the party organization. Also the daily activity of the Procuracy is subjected to the strict control of the party organizations. ${ }^{61)}$ Cases of undue interference of the party organizations are reported from time to time. As a result of the

56. Sotsialisticheskaia Zakonnost', 1978, No. 11, pp. 58-59; No. 12, p. 57.

57. M. P. Maliarov ed., Organizatsiia raboty raionnoi prokuraturyi, Moscow, 1974, pp. 129-139.

58. K. F. Skvortsev, Sovetskaia prokuratura i obshchestvennost', in Uchastie obshchestvennosti v bor'be s pravonarusheniiami v SSSR, Moscow, 1978, p. 44.

59. Sovetskoe Gosudarstvo i Pravo, 1966, No. 1, p. 134.

60. Ibid.

61. S. E. Zhilinskii, Rol' KPSS v ukreplenii zakonnosti na sovremennom etape, Moscow, 1977, p. 10; R. Sharlet, "The Communist Party and the Administration of Justice in the USSR", D. Barry et al eds., Soviet Law after Stalin, vol. 3, Alphen aan den Rijn, 1979, pp. 326-360. 
close relationship between the Party and the Procuracy, when party policy and the law came in to conflict, the Procuracy turned into the executioner of party policy instead of being a guardian of legality. ${ }^{62)}$ The Constitution of 1977 defined the legal status of the party for the first time in the history of Constitution in Soviet Russia. ${ }^{63)}$ Some procurators asserted that the leading role of the party in relation to the Procuracy should also be defined in the new law. ${ }^{64)}$ According to the law on the Procuracy of the DDR, actualization of the party policy is one of the functions of the Procuracy. DDR law also provides for the cooperation of the party organization and the Procuracy. ${ }^{65)}$ However, unlike the DDR law, the new law did not specifically refer to this matter. It only added "political and ethical quality" as a requirement for becoming a procurator.

To conclude, the new law on the Procuracy adjusted the statute of 1955 to the other legislation which underwent a major reform after the promulgation of the statute. It also corrected various shortcomings of the statute and defined the function, competence and the form of action of the Procuracy in a more detailed way than the 1955 statute. Thus, several issues which were not clear in the previous statute were clarified by the new law. Furthermore, it should be noted that the competence of the Procuracy was widened and its power was strengthened in several points.

This reform of the law on the Procuracy is closely related to the fact that recently in the Soviet Union, the preservation of law and order and the "liquidation" of violations of the law are repeatedly emphasized. The decision of the Central Committee of the Communist Party of 1979 criticized the ineffectiveness of the activities of the agencies in charge of protecting law and order, including the Procuracy, and recommended these agencies to intensify their activities and to increase their effectiveness. ${ }^{66)}$ This drive for law and order, or rather, state and social discipline, had some effect on the reform of the law on the Procuracy. The reform seems to have been motivated by the

62. H. Oda, "Revolutionary Legality in the USSR: 1928-1930", Review of Socialist Law, June, 1980, pp. 141-151.

63. Art. 6 of the USSR Constitution.

64. Sotsialisticheskaia Zakonnost', 1978, No. 7, p. 34.

65. H. Roggemann ed., Die Gesetzgebung der DDR, Bd. 2.

66. Kommunist, 1979, No. 14, pp. 3-6. 
intention of the legislators to rationalize the activities of the Procuracy and to make it more effective as a means of securing law and order. However, since the fundamental function and the structure of the Procuracy remain unchanged, it does not seem to be conceivable that the intentions of the legislators can be realized in the near future.

On the other hand, it is worth noting that little concern was given to improving the effectiveness of the Procuracy as an agency of administrative remedy. Moreover, proposals for the introduction of certain democratic principles, for example, the principle of openness in the activities of the Procuracy, were not accepted. 